\title{
Vpliv pretoka zraka na sušenje krme na sušilnih napravah
}

\author{
Janez BENEDIČIČ ${ }^{1,2}$, Rajko BERNIK ${ }^{3}$
}

Received July 10, 2019; accepted July 15, 2019. Delo je prispelo 10. julija 2019, sprejeto 15. julija 2019.

Vpliv pretoka zraka na sušenje krme na sušilnih napravah Izvleček: V alpskih državah Evrope sušenje krme s travinja postaja vedno bolj pomembno zaradi ugotovljenih pozitivnih učinkov na maščobno kislinsko sestavo mleka. S pravilnim postopkom in tehnologijo dosuševanja krme se lahko kvaliteta dvigne na primerljiv nivo travnih silaž. Sušenje temelji na odvzemu vlage iz krme s pomočjo prevetrovanja - zraka, ki je ključen za hitrost sušenja. Poleg majhne relativne vlažnosti zraka je pomemben tudi njegov pretok skozi krmo. V literaturi se navaja spodnja mejna vrednost pretoka zraka in zgornja mejna vrednost, pri čemer je razlika $85 \%$. Članek opisuje izvedeni eksperiment merjenja porabe energije in učinkovitosti sušenja pri običajno v praksi uporabljenem manjšem in večjem pretoku zraka. Izkazalo se je, da pri večjem pretoku zrak porabimo za 38 \% več energije na izločen kilogram vode, kot pa pri manjšem pretoku. Izvedeni preizkus dokazuje, da sušenje $\mathrm{z}$ velikim pretokom zraka ne prinese enako večji učinek.

Ključne besede: pretok zraka; sušenje krme; sušilna naprava; izločena voda; energija
The effect of air flow on drying fodder on drying systems

Abstract: Drying grass fodder in Europe's Alpine countries is becoming increasingly important due to positive effects on the fatty acid composition of milk. A proper approach and technology of fodder drying can raise its quality to the level of grass silage. In principle, drying fodder means extracting water from fodder by means of ventilation - the air, the key to the speed of drying. Besides low relative air humidity, its flow rate through the fodder is also important. In the literature, the lower- and upper-bound limits of air flow rates can be found, with a difference of $85 \%$ between the two. The article describes a test, measuring energy consumption and the efficiency of drying at a low air flow, often used in practice, and a high air flow. It was found that a high air flow results in $38 \%$ higher energy consumption per kilogramme of extracted water, compared to a low air flow. The executed test has proved that drying at a higher air flow will not have a proportionally greater effect.

Key words: air flow; drying fodder; drying system; energy; water extracted

1 Univerza v Ljubljani, Fakulteta za strojništvo, Laboratorij LECAD

2 Korespondenčni avtor, e-naslov: janez.benedicic@fs.uni-lj.si

3 Univerza v Ljubljani, Biotehniška fakulteta, Oddelek za agronomijo 


\section{UVOD}

Kmetje, sirarne in mlekarne iščejo nove priložnosti in tržne niše za prodajo pridelkov in izdelkov. Ena izmed tržnih niš, ki je bila prepoznana tudi v Sloveniji, je seneno mleko in seneno meso. Za ekonomično prirejo senenega mleka in mesa je ključno seno. To predstavlja pomemben del krmnega obroka, zato je še toliko pomembnejša njegova kakovost. V Sloveniji je sušenje krme s travinja precej razširjeno. Rezultati popisa na kmetijah v kontroli prireje mleka (5.198 kmetij) kažejo, da na približno $1 / 3$ kmetij prevladuje siliranje, na $1 / 3$ kmetij krmo samo sušijo ali pretežno sušijo, na $1 / 3$ pa sta sušenje in siliranje zastopana enakovredno (Verbič in sod., 2006). Priprava sena poteka pretežno na prostem. Na sušilnih napravah posuši večji del sena le slaba tretjina kmetov (Verbič in sod., 2006). Temu primerna je tudi kakovost mrve. Rezultati analiz sena s kmetij, ki so jih v obdobju 2000-2010 opravili v slovenskih laboratorijih kažejo, da vsebuje seno v povprečju le 5,05 MJ NEL (neto energije za laktacijo) na kg sušine, kar je za $15 \%$ manj kot pri travnih silažah (Verbič in sod, 2011). Kakovost sena je odvisna od kakovosti pokošene krme, ter od izgub in sprememb krme med sušenjem in skladiščenjem. Sušenje ali dosuševanje sena na tradicionalnih sušilih (kozolci, ostrvi), prevetrovalnih napravah s hladnim ali toplim zrakom ali na kondenzacijskih sušilnicah brez dvoma prispeva $\mathrm{k}$ boljši kakovosti sena. Avstrijska študija je na vzorcu, ki je vključeval prek 500 kmetij, pokazala, da suši seno na tleh manj kot ena tretjina kmetov (27,8 \%), da 39,0 \% kmetov seno prevetruje s hladnim zrakom, 33,2 \% pa s toplim zrakom (Resch in sod., 2011). Na 6,3 \% od vseh kmetij, ki seno dosušujejo na sušilnih napravah, izvajajo sušenje $\mathrm{v}$ valjastih balah. Rezultati analiz so pokazali, da je v Avstriji dosuševano seno precej boljše od sena, ki je sušeno na tleh. Pridelava kakovostnega sena je mogoča samo z dodatnim sušenjem na sušilnih napravah, saj pride pri sušenju na tleh do prevelikih izgub zaradi drobljenja krhkih delov travniških rastlin (lahko tudi do $30 \%$ ) in s tem do zmanjšanja hranilne vrednosti pridelanega sena. Poleg tega $s$ sušenjem na sušilnih napravah zmanjšamo tveganja povezana $\mathrm{z}$ neugodnimi vremenskimi razmera$\mathrm{mi}$ in se izognemo zmanjšanju hranilne vrednosti krme zaradi morebitnega dežja med spravilom. Sušenje s hladnim zrakom se večinoma prakticira od $30 \%$ vlažnosti krme navzdol. Pri tem pa prihaja tudi že do povečanega drobljenja najobčutljivejših delov rastlin. Razlika med izgubami zaradi drobljenja med $50 \%$ vlažnostjo krme in $30 \%$ vlažnostjo krme je v povprečju $4 \%$ do $5 \%$, lahko tudi 8 \% (Frick in sod., 1999). Osnovni princip sušenja krme je tako pogojen z zagotavljanjem pretoka zraka skozi krmo. Tehnološki princip sušenja sena v boksu je sestavljen iz ventilatorja, ki zagotavlja pretok zraka in boksa z rešetko čez celotno površino, ki omogoča, da zrak enakomerno prehaja skozi krmo in jo suši. Pri sušenju bal ventilator zrak vpihava $\mathrm{v}$ kanal na katerem so položene bale. Zrak prehaja skoznje in jih suši. Osnovni princip velja za katerokoli poznano tehnologijo sušenja krme. Pretok zraka lahko rečemo, da je ključen za odvzem vlage krmi. Pri prehodu zraka ustrezne vlažnosti skozi krmo se nanj veže voda iz krme. Logično razmišljane bi bilo, da čim večja količina zraka gre skozi krmo pomeni hitrejše in s tem učinkovitejše sušenje, vendar temu ni tako, kar bo potrjeno tudi v preizkusu. Na sušilnih napravah imamo običajno na voljo omejeno količino toplote za dogrevanje, količino vpihanega zraka pa se lahko spreminja. Literatura navaja različne hitrosti/količine zraka skozi krmo. Vrednosti so različne za bale in za sušenje sena v razsutem stanju. Pri sušenju bal se navaja vrednost $\mathrm{v}$ količini zraka na balo. Ta je opredeljena med $1100 \mathrm{~m}^{3} \mathrm{~h}^{-1}$ in $1500 \mathrm{~m}^{3} \mathrm{~h}^{-1}$ (Wirleitner, 2013). Pri sušenju sena v razsutem stanju je večji razpon med spodnjo in zgornjo priporočeno mejo in sicer med $0,07 \mathrm{~m}^{3} \mathrm{~s}^{-1} \mathrm{~m}^{-2}$ in $0,13 \mathrm{~m}^{3} \mathrm{~s}^{-1} \mathrm{~m}^{-2}$ površine sušilnega prostora (Wirleitner, 2011).

\section{MATERIAL IN METODE}

\subsection{OSNOVNI PRINCIP SUŠENJA KRME}

Bistvo procesa sušenja je, da $\mathrm{v}$ krmi zmanjšamo vsebnost vlage na skladiščno vrednost. Seno je dovolj suho za skladiščenje, če vsebuje najmanj 86 \% SS (suhe snovi). Voda je $\mathrm{v}$ rastlinah prisotna $\mathrm{v}$ celicah in medceličnem prostoru, ki nato prehaja na površino rastline (Daszkowska-Golec in Szarejko, 2013). Pri gibanju zraka ob površini rastline se voda uparja - izhlapeva do nasičenosti plasti zraka, ki potuje ob rastlini. Zrak je nasičen z vodno paro - vlago, ko doseže relativno vlažnost $100 \%$. Relativna vlažnost se meri v procentih, absolutna pa se običajno podaja v g vode na kilogram zraka. Mejne vrednosti absolutne vlažnosti zraka so odvisne od temperature zraka (Tabela 1). Pri temperaturi $20^{\circ} \mathrm{C} 1 \mathrm{~kg}$ zraka

Tabela 1: Absolutna in relativna vlažnost zraka Table 1: Absolute and relative air humidity.

\begin{tabular}{lll}
\hline $\begin{array}{l}\text { T zraka } \\
{\left[{ }^{\circ} \mathrm{C}\right]}\end{array}$ & $\begin{array}{l}\text { Relativna vlažnost } \\
{[\%]}\end{array}$ & $\begin{array}{l}\text { Absolutna vlažnost } \\
{[\mathrm{g} \mathrm{kg}-1]}\end{array}$ \\
\hline 20 & 65 & 11 \\
20 & 100 & 14,7 \\
25 & 65 & 15 \\
25 & 100 & 20,1 \\
\hline
\end{tabular}




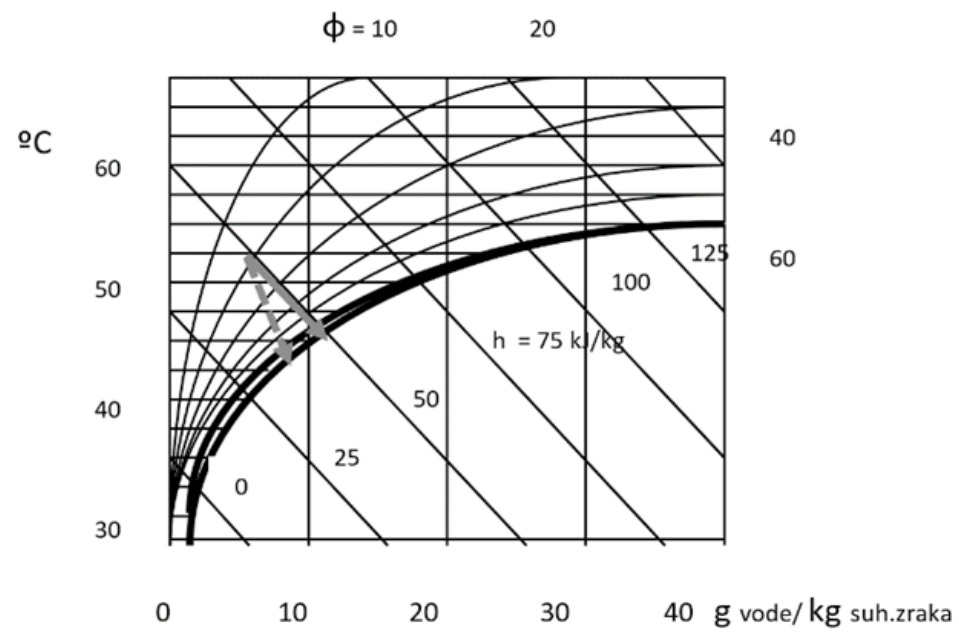

Slika 1: Prikaz adiabatnega vlaženja v h-x diagram (Benedičič in Verbič, 2013)

Figure 1: Adiabatic moisturising, shown on an h-x diagram (Benedičič and Verbič, 2013)

lahko sprejme $14,7 \mathrm{~g}$ vode, pri $25^{\circ} \mathrm{C}$ pa $20,14 \mathrm{~g}$ vode, kar pomeni 37 \% več (Sargent, 1980). Sušenje pri višjih temperaturah je zato hitrejše.

Uporaba sistemov sušenja v praksi je pokazala, da pri hladnem prevetrovanju lahko upoštevamo povprečen odvzem največ $1 \mathrm{~g}$ vode na $\mathrm{m} 3$ vpihanega zraka, pri uporabi sončne strehe $2 \mathrm{~g}$ vode na $\mathrm{m} 3$ vpihanega zraka in pri sušenju $\mathrm{s}$ toplotno črpalko tudi $5 \mathrm{~g}$ vode na $\mathrm{m} 3$ zraka. Pri odvzemu $0,47 \mathrm{~g}$ vode na $\mathrm{m} 3$ se zrak ohladi za $1^{\circ} \mathrm{C}$ (Wirleitner, 2011). To velja za idealni adiabatni proces. Sistem vlaženja zraka poteka adiabatno (Rant, 2011). Na sliki 1 je prikazan idealen adiabatni proces (polna črta), medtem ko je s prekinjeno črto prikazan dejanski proces. Razlika nastane zaradi izgube toplote.

\subsection{TOPLOTA ZA SUŠENJE}

$\mathrm{Z}$ razvojem tehnologij segrevanja zraka in poznavanjem mehanizma adiabatnega sušenja so se poleg hladnega prevetrovanja in prevetrovanja $\mathrm{z}$ zrakom izpod kritine razvili tudi sistemi prevetrovanja s toplim zrakom, ki jih delimo glede na vir energije: biomasa (kot vir toplote se uporabljajo drva, peleti, sekanci, žagovina); kurilno olje; plin; električna energija (toplotna črpalka).
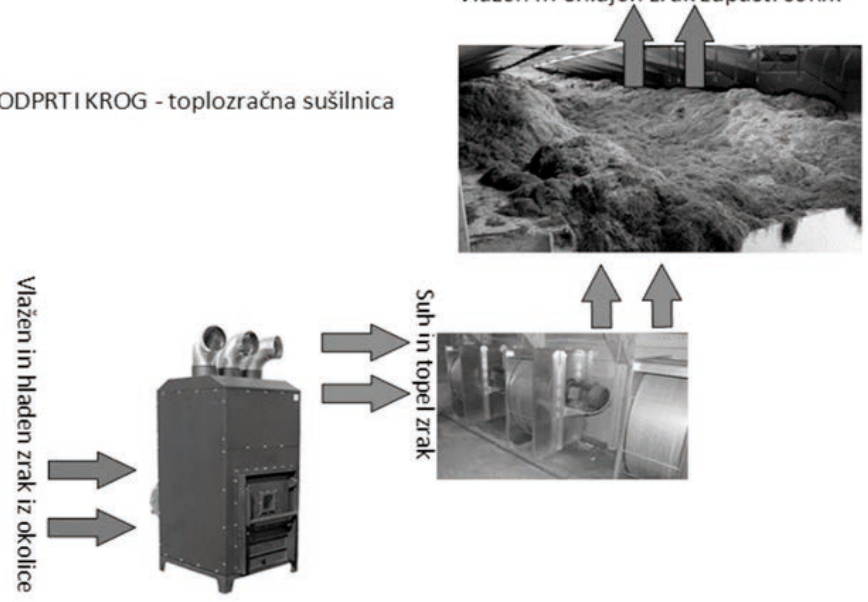

Slika 2: Odprt zračni tok

Figure 2: Open air flow. 


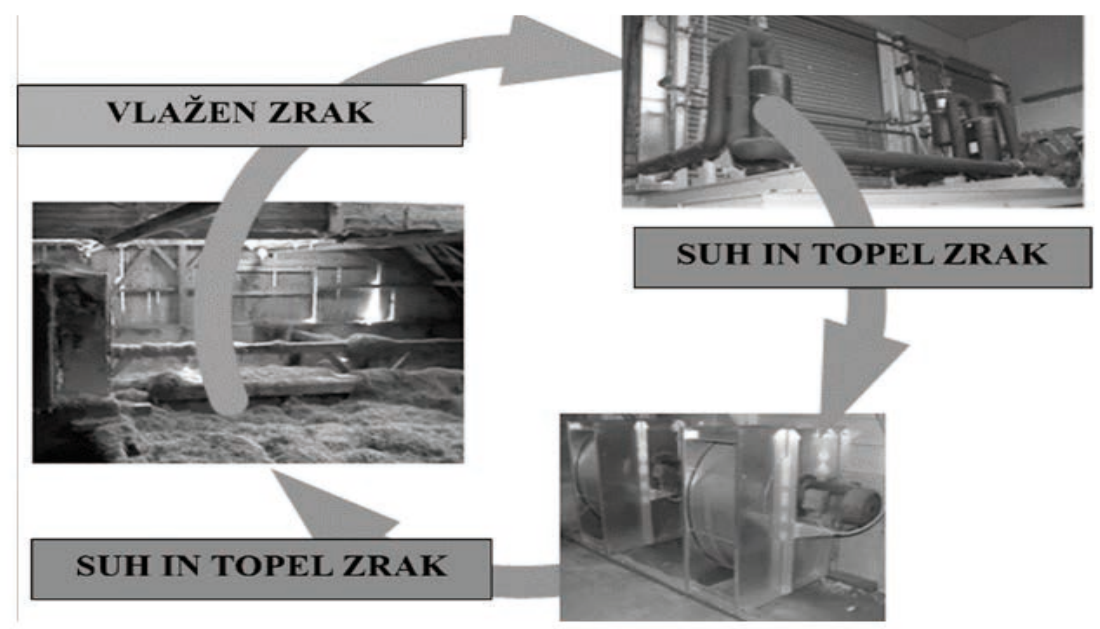

Slika 3: Zaprt zračni tok

Figure 3: Closed air flow

Biomasa, kurilno olje in plin z gorenjem proizvajajo toploto. V primeru toplozračnih peči toplota prehaja direktno na zrak, v primeru peči v katerih se segreva voda, se toplota s pomočjo toplovoda transportira do sušilne naprave kjer preko toplotnega izmenjevalca segreva zrak.

\subsection{POTEK ZRAČNEGA TOKA PRI SUŠENJU}

V osnovi ločimo sušenje $\mathrm{v}$ odprtem zračnem krogu in sušenje v zaprtem zračnem krogu. Sušenje v zaprtem zračnem krogu je sušenje $s$ toplotno črpalko, medtem ko so vsa ostala sušenja (biomasa, plin, toplota iz bioplinarn...) v odprtem zračnem toku.

Pri odprtem zračnem toku (Slika 2) zrak sesamo iz okolice in ga preko enega izmed prej omenjenih načinov segrevamo, pri čemer se mu zmanjša relativna vlaga. Nato ga vpihavamo v sušilni boks ali bale. Zrak se pri potovanju skozi krmo navlaži in ohladi, nato ga odvajamo iz sušilne komore v okolico. Slaba stran sušenja v odprtem krogu je v tem, da vedno sesamo zrak in okolice in ga dogrevamo. To lahko predstavlja problem $\mathrm{v}$ mrzlih spomladanskih in jesenskih nočeh. Če je zunanja nočna temperatura $5^{\circ} \mathrm{C}$ in segrevate zrak za $15^{\circ} \mathrm{C}$, temperatura vstopa zraka v boks ne bo višja kot $20^{\circ} \mathrm{C}$. Glede na zgor-

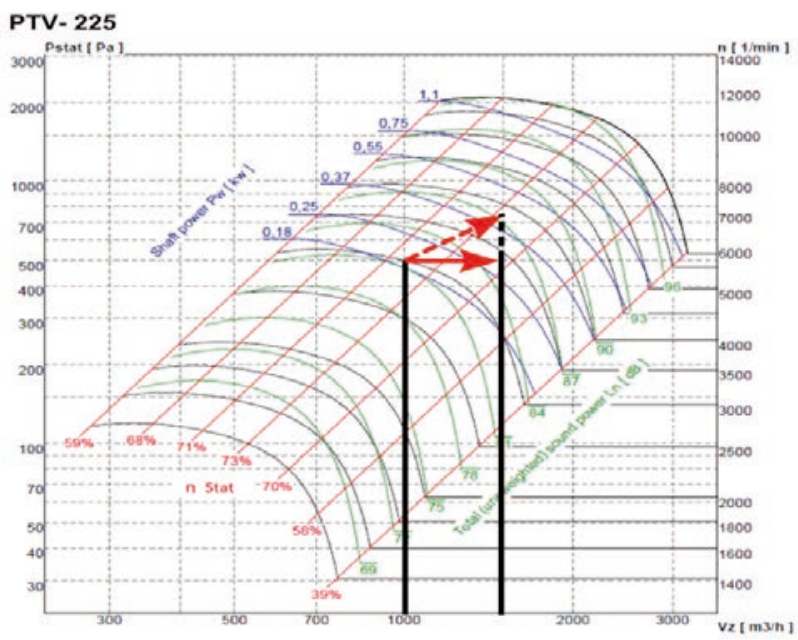

Slika 4: Karakteristika ventilatorja Oravent PTV 225 s primerom povečanja pretoka

Figure 4: Oravent PTV 225 fan characteristics with an example of increased flow. 
nje ugotovitve je sposobnost zraka za odvzem vlage na $1 \mathrm{~m}^{3}$ pri nižji temperaturi nižja kot pri višjih temperaturah. (Tabela 1).

Zaprt zračni tok (Slika 3) je značilen za kondenzacijske sušilnice. Zrak kroži od ventilatorjev preko sena kjer se navlaži do toplotne črpalke, ki ga razvlaži in segreje, ter nato ponovno do ventilatorjev. Krog potovanja zraka je tako zaprt in sklenjen. Takšen sistem ni odvisen od zunanjega vremena in zunanje temperature. Učinek sušenja je večji, saj praviloma tudi pri nizkih zunanjih temperaturah in pravilno dimenzioniranem sistemu temperatura vpihanega zraka v seno ni nižja kot $25^{\circ} \mathrm{C}$ do $30^{\circ} \mathrm{C}$, kar pomeni večjo možnost odvezam vode iz krme (Tabela 1).

Osrednji element vsake sušilne naprave je ventilator. Ta zagotavlja potreben pretok zraka, ki mora premagovati odpor pri prehodu zraka skozi krmo. Temu pravimo, da ventilator zagotavlja potreben statični tlak za premagovanje odpora pri pretoku zraka. Medsebojni vpliv je obratno sorazmeren. Na sliki 4 je prikazan vpliv povečanja pretoka na povečanje potrebne moči za pogon ventilatorja. $V$ prvem primeru (puščica s polno črto) se pretok pri konstantnem tlaku poveča iz $1000 \mathrm{~m}^{3} \mathrm{~h}^{-1}$ na $1500 \mathrm{~m}^{3} \mathrm{~h}^{-1}$, posledično se poveča potrebna moč iz $0,19 \mathrm{~kW}$ na $0,30 \mathrm{~kW}$. Realno se pri povečanju pretoka zraka skozi krmo poveča tudi upor in s tem potreben statični tlak. Na sliki 4 je prikazan primer (puščica s črtkano črto) istočasnega povečanj pretoka zraka in upora. Potrebna moč ventilatorja se dvigne iz $0,19 \mathrm{~kW}$ na $0,43 \mathrm{~kW}$, kot prikazuje slika 4 . Večji pretok zraka pomeni večjo potrebno moč in $s$ tem večjo porabo energije (Wirleitner, 2013).

\subsection{PARAMETRI PREIZKUSA}

Kmet kot odločevalec in investitor se odloča za uvedbo določene tehnologije tudi na podlagi predvidenega povečanja produktivnosti, uvedbe novih izdelkov ali zmanjšanja stroškov. Poleg dodane vrednosti pri trženju novih izdelkov je stroškovni vidik eden izmed pomembnejših pri uvedbi tehnologije sušenja na kmetiji ali kmetijskem podjetju. Stroški sušenja so eden izmed spremljanih parametrov preizkusa. Izražen bo v obliki porabljene energije glede na izločeno vodo. Manjša je poraba energije na enoto izločene vode učinkovitejše in cenejše je sušenje. Naslednji parameter, ki smo ga spremljali je masa izločene vode. Osnovni cilj sušenja je izločiti čim več vode iz rastlin in s tem rastlino posušiti. Intenzivnost sušenja je mogoče definirati v masi izločene vode na časovno enoto. Čim večja je ta, tem hitrejše in učinkovitejše je sušenje. Pretok zraka ne bo opazovan ampak predhodno nastavljen na dve vrednosti in sicer spodnjo vrednost $0,85 \mathrm{~m}^{3} \mathrm{~s}^{-1} \mathrm{~m}^{-2}$ in zgornjo vrednost $0,13 \mathrm{~m}^{3} \mathrm{~s}^{-1} \mathrm{~m}^{-2}$.

\subsection{PREIZKUS}

V okviru preizkusa smo sušili lucerno. Ta je vse pomembnejša krmna rastlina. Po podatkih Statističnega urada smo jo v Sloveniji v devetdesetih letih prejšnjega stoletja pridelovali na približno 10.000 ha. Nato se je njena uporaba močno zmanjšala. Predvsem zaradi finančnih podpor za beljakovinske rastline v okviru shem neposrednih plačil se zanimanje za pridelovanje lucerne spet povečuje, tako da smo jo v letu 2016 pridelovali že na približno 5600 ha. Sušenje lucerne v razsutem stanju je bilo izvedeno v posebej pripravljenem testnem zabojniku (Slika 5).

Zabojnik je bil kvadratne oblike $\mathrm{z}$ dimenzijo stra-

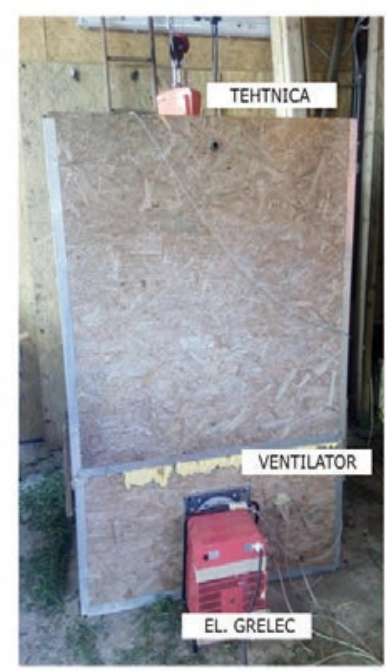

Slika 5: Testni zabojnik za izvedbo preizkusa

Figure 5: Test box for test execution. 
nice $1,25 \mathrm{~m}$ in višino $2 \mathrm{~m}$. Izdelan je bil kot sušilni boks za razsuto stanje krme. V spodnjem delu v oddaljenosti $0,3 \mathrm{~m}$ od dna zabojnika je bila nameščena rešetka. Pod to rešetko je bil na bočni strani zalogovnika nameščen frekvenčno krmiljeni ventilator in električni grelec stalne toplotne moči $9 \mathrm{~kW}$. Višina nalaganja krme v zalogovnik je bila 1,7 m. Na zgornji strani je bil zalogovnik nihajno vpet na tehtnico, ki je beležila spremembo teže zaradi izhlapele vode iz sušeče se krme. Ventilator je zrak preko električnega grelca sesal iz okolice in ga vpihoval pod rešetko na dnu zabojnika. Sistem je deloval na principu odprto krožnega načina sušenja. Zrak za sušenje smo zajemali iz okolice, izhodni zrak iz zabojnika pa se je odvajal v okolico Med sušenjem smo spremljali maso zabojnika s krmo in tako določili maso izhlapele vode. Sušenje je potekalo intervalno med manjšim pretokom zraka $\left(0,85 \mathrm{~m}^{3} \mathrm{~s}^{-1} \mathrm{~m}^{-2}\right)$ in večjim pretokom zraka $\left(0,13 \mathrm{~m}^{3} \mathrm{~s}^{-1} \mathrm{~m}^{-2}\right)$. Ne glede na pretok zraka, smo dovedenemu zraku dovajali $9 \mathrm{~kW}$ toplotne energije na uro. Sušenje je potekalo 12 ur s šestimi izmeničnimi intervali (prvi interval sušenje $\mathrm{z}$ manjšin pretokom, drugi $\mathrm{z}$ večjim pretokom, naslednji ponovno $\mathrm{z}$ manjšim, ...).

\section{REZULTATI IN RAZPRAVA}

Preizkus je potekal 12 ur. V tem času smo izločili $38,5 \mathrm{~kg}$ vode. Ventilator je pri manjšem pretoku $\left(0,85 \mathrm{~m}^{3} \mathrm{~s}^{-1} \mathrm{~m}^{-2}\right)$ imel porabo električne energije $27 \mathrm{~W} \mathrm{~h}$, pri večjem pretoku $\left(0,13 \mathrm{~m}^{3} \mathrm{~s}^{-1} \mathrm{~m}^{-2}\right)$ pa $43 \mathrm{~W}$ h. V povprečju smo pri manjšem pretoku na izločili $3,01 \mathrm{~kg}$ vode na uro sušenja, pri večjem pretoku pa $3,48 \mathrm{~kg}$ vode na uro sušenja. Količina izločene vode pri manjšem pretoku se med posameznimi intervali ni bistveno razlikovala (v povprečju za $1 \%$ ), med tem ko se je pri višjih intervalih v povprečju za $6 \%$. V Kolikor preračunamo količino izločene vode na pretok zraka ugotovimo, da se je pri manjšem pretoku izločalo 6,02 g vode na $\mathrm{m}^{3}$ zraka, pri večjem pretoku pa $4,97 \mathrm{~g}$ vode na $\mathrm{m}^{3}$ zraka. Iz dobljenih rezultatov ugotovimo, da vrednost pretoka zraka ni merilo za merjenje učinkovitosti sušenja ampak to mora bit povezano z količino izločene vode. Rezultati kažejo, da $40 \%$ večji pretok zraka omogoči le $21 \%$ večje izločanje vode. Glede na časovno enoto pa to pomeni le $15 \%$ več izločene vode na uro. Zanimiva je tudi ugotovitev, da pri večjem pretoku zraka izločanje vode na enoto pretoka zraka hitreje pada kot pri manjšem pretoku zraka. Rezultati preizkusa potrjujejo, da voda $\mathrm{v}$ rastlinah potrebuje določen čas, za prehod iz rastlin v vodno paro zraka. Prevelika hitrost zraka skozi krmo pomeni manjše nasičenje zraka $\mathrm{z}$ vlago in s tem manjšo učinkovitost sistema.

Drug spremljan parameter je bila poraba energije za pogon ventilatorja. Statični tlak v zabojniku se skozi su- šenje ni spreminjal, tako da je bila poraba energije v posameznih intervalih enaka $(27 \mathrm{~W}$ h pri manjšem pretoku in $43 \mathrm{~W}$ h pri večjem pretoku). Glede na izločeno vodo je na $\mathrm{kg}$ izločene vode porabil $8,99 \mathrm{~W}$ h pri večjem pretoku pa $12,4 \mathrm{~W}$ h. Povečanje porabe energije glede na izločen kilogram vode je bil tako $38 \%$.

\section{ZAKLJUČEK}

$\mathrm{V}$ literaturi navedeni razpon med manjšim in večjim pretokom zraka je absolutno prevelik. Z večjim pretokom zraka ne dvigujemo učinkovitosti sistema, ampak le stroške sušenja. Pri 40 \% večjem pretoku zraka je poraba energije za pogon ventilatorja za 38 \% večja, kljub temu, da je sušenje le za 15 \% učinkovitejše. V preizkusu smo primerjali dve vrednosti pretoka zraka, večjo in manjšo. Postavi se vprašanje ali je manjša vrednost pretoka zraka že optimalna vrednost? Ali bi z dodatnim manjšanjem pretoka zraka dosegli še boljše rezultate? Na to bi lahko odgovorili z novimi preizkusi, predvsem pa $\mathrm{z}$ raziskavo mehanizma prestopa vode iz rastline na zrak, ki rastlino obteka. S poznavanjem teh parametrov bi lahko nadaljevali optimiranje sušenja krme.

\section{LITERATURA}

Benedičič, J., \& Verbič, J. (2013). Sušenje lucerne s kondenzacijsko sušilnico = Alfalfa drying by the use of condensation dryer. V: ČEH, Tatjana (ur.), KAPUN, Stanko (ur.). Proceedings of the 22nd International Scientific Symposium on Nutrition of Farm Animals: Zadravec-Erjavec Days 2013, Radenci, 14th and 15th November 2013. Murska Sobota: Kmetijsko gozdarska zbornica Slovenije, Kmetijsko gozdarski zavod, str. 67-71.

Daszkowska-Golec, A. and Szarejko, I. (2013). Open or Close the Gate - Stomata Action Under the Control of Phytohormones in Drought Stress Conditions. Frontiers in Plant Science, 4. https://doi.org/10.3389/fpls.2013.00138

Frick, R., Ammann, H., Wyss, U., Daccord, R. (1999) Einsatz von Intensivaufbereitern in der Futterwerbung. FAT Berichte, 532, Tänikon, Eidgenössische Forschungsanstalt für Agrarwirtschaft und Landtechnik, str. 20.

Rant, Z. (2011). Termodinamika knjiga za uk in prakso, Fakulteta za strojništvo, str. 609

Resch, R., Buchgraber, K., Wiedner, G., Frank, P., Meusburger, C., Pichler, M., Stromberger, W., Tiefenthaller, F., Wurm, K. Praxisheu. (2011). Raufutterqualität auf österreichischen Betrieben. Irdning, Lehr- und Forschungszentrum für Landwirtschaft Raumberg-Gumpenstein, str. 56.

Sargent, G. P., 1980: Computation of vapour pressure, dewpoint and relative humidity from dry- and wet-bulb temperatures. Meteorological Magazine, 109, 238-246.

Verbič J., Babnik D., Jeretina J., Perpar T. (2006). Navade rejcev pri krmljenju krav v Sloveniji in njihov vpliv na mlečnost, 
sestavo mleka in zdravstveno stanje. V: Zbornik predavanj 15. posvetovanja o prehrani domačih živali „ZadravčeviErjavčevi dnevi“. Kapun, S. (ur.), Čeh, T. (ur.). Murska Sobota, Kmetijsko gozdarska zbornica Slovenije in Kmetijsko gozdarski zavod Murska Sobota, 119-135.

Wirleitner, G. (2011). Energieefficienter Heutrocknungstech- nik 2011, Heugala 2011, Bundesanstalt für alpenländische Landwirtschaft Gumpenstein.

Wirleitner, G. (2013). Neue Dimensionen in der Rundballentrocknung, Bautagung Raumberg - Gumpenstein 2013, Raumberg Gumpenstein. 